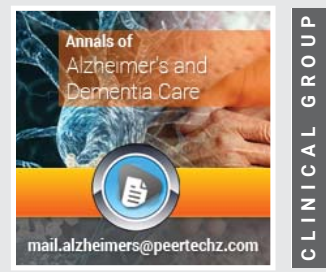

\title{
Alzheimer's Disease: Risk factors and Prevention
}

\author{
Sununta Youngwanichsetha* \\ Faculty of Nursing, Prince of Songkla University, Songkla, Thailand
}

Received: 16 March, 2020

Accepted: 21 May, 2020

Published: 22 May, 2020

*Corresponding author: Sununta Youngwanichsetha, Faculty of Nursing, Prince of Songkla University, Songkla 90112, Thailand, Tel: 66-074-286537;

E-mail: sununta.y@psu.ac.th

https://www.peertechz.com
The prevalence of Alzheimer's disease among population worldwide is increasing because of unrecognizing of its risk factors and unawareness of adopting modification of preventive behaviors. It is estimated that almost two thirds of individuals with Alzheimer's disease are women. Postmenopausal women with obesity and diabetes are more likely to have Alzheimer's disease. Eighty percent of patient with Alzheimer's disease also have type 2 diabetes. Knowing the significant factors and effective interventions would be helpful to initiation of primary prevention, early detection and management.

Alzheimer's disease is manifested with chronic inflammation and neuronal cell death in the hippocampus region of the brain. It can be classified into four stages: 1) mild cognitive impairment, 2) mild Alzheimer's disease, 3) moderate Alzheimer's disease, and 4) severe Alzheimer's disease. Mild cognitive impairment is diagnosed when the disease begins in medial temporal lobes. Mild Alzheimer's disease is diagnosed when the disease spreads to lateral and parietal lobes. Moderate Alzheimer's disease is diagnosed when the disease spreads to frontal lobes. Severe Alzheimer's disease is diagnosed when the disease spreads to occipital lobes. These pathological manifestations are gradual and progressive neural cell damage and death. Common manifestations of Alzheimer's clinical symptoms are loss of short-time memory, irritability, confusion, speech violation, problems in abstract thinking, speaking, reading, and writing, poor reasoning and judgement, dementia, depression, difficulty in doing simple tasks and daily self-care activities. These intellectual decline and physical complications result in disability, independence, poor quality of life, death and caregiver burden.

Previous studies reveal that obesity and high levels of blood glucose result in development of Alzheimer's disease. Sugar also has an effect on cognitive decline and memory function in rodents and rat models. Overconsumption of sugar is associated with endothelial ${ }_{\text {GLUT1 }}$ deficiency and brain damage [1-5]. A systematic review shows that type 2 diabetes patients are more likely to develop dementia and brain-related complications.
Overconsumption of refined carbohydrate, sugar and fructose, causes elevated of blood glucose levels, mitochondrial dysfunction, oxidative stress, insulin resistance and hyperinsulinemia affecting amyloid plaques formation, and inflammation of the neurons. Research evidence shows that average blood glucose of $190 \mathrm{mg} / \mathrm{dL}$ had a $40 \%$ higher risk of dementia from Alzheimer's disease than diabetes patients with average blood glucose of $160 \mathrm{mg} / \mathrm{dL}$. These pathogenesis manifestations affect the brain metabolism of glucose at the neural cell membrane and microtubules. Beta-amyloid peptide forms oligomers, fibrils, amyloid plaque and microtubule disintegration in neurons leading to cognitive and intellectual impairment, brain atrophy and death. Therefore, promotion of neuron health should be the focus to prevent the development of Alzheimer's disease [6-10].

Prior research evidences suggest that healthy dietary patterns and physical exercise can prevent and delay the development of Alzheimer's disease. Essential nutrients for the brain metabolism is promote healthy neuron whereas foods containing carbohydrate and sugar damage neuron cells. Examples of ketogenic diets and glutathione rich foods can improve brain neuron function such as, lean meat, fish, eggs, milk, cheese, almond, avocado, broccoli, green leafy veggies, pumpkin seeds, and low glycemic index foods. These essential proteins, vitamin, glutathione, and antioxidants will promote healthy neurons and its function. In addition, metabolic healthy education should be informed and advised to decrease overconsumption of refined carbohydrate, sugar, fructose and unhealthy foods rich in advanced glycation end products in order to lower the risk of hyperglycemia, insulin resistance, hyperinsulinemia, amyloid plaques, dying neurons and its consequence complications.

Moreover, regularly doing moderate intensity exercise would be promoted for all in order to increase glucose uptake in muscle cells and other organs. Aerobic and resistance exercise can decrease insulin resistance and improve insulin 
sensitivity. Favorite exercise should be scheduled within a week at least 150 minutes or 600 metabolic equivalent minutes (MET minutes) of physical activity spreading throughout 3-5 days. Examples of recommended exercise are running, brisk walking, swimming, bicycle riding, stationary cycling, outdoor sports. As a result, cellular oxidative stress, mitochondrial dysfunction, inflammation, amyloid plaques formation, dying neurons and Alzheimer's disease will be prevented [11-15].

Finally, implementations of preventive behavior modification are essential to raise awareness and motivation to reduce or avoid consumption of sugar-sweetened beverages and desserts. Promotion of metabolic health literacy is important strategy to educate clearly understanding on the effect of sugar on Alzheimer's disease and associated diseases.

\section{References}

1. Beam CR, Kaneshiro C, Jang JY, Reynolds AC, Pedersen NL, et al. (2018) Differences between women and men in incidence rates of dementia and Alzheimer's disease. J Alzheimers Dis 64: 1077-1083. Link: https://bit.ly/3e8QNjh

2. Bondi MW, Edmonds EC, Salmon DP (2019) Alzheimer's disease: past, present, and future. J Int Neuropsychol Soc 23: 818-831. Link: https://bit.ly/36kzUj0

3. Borley G, Hardy S (2017) A qualitative study on becoming cared for Alzheimer's disease: the effects to women's sense of identity. Aging Ment Health 21 1017-1022. Link: https://bit.ly/2XiJWgx

4. Dolan C, Glynn R, Lawlor B (2020) A systematic review and Delphi study to ascertain common risk factors for type 2 diabetes mellitus and dementia and brain-related complication of diabetes in adults. Can J Diabetes 44: 1-8. Link: https://bit.ly/2ZtkJ5x

5. Driscoll I, Snively BM, Espeland MA, Shumaker SA. Rapp RS, et al. (2019) A candidate gene study of risk for dementia in older, postmenopausal women: results from the women's health initiative memory study. Int J Geriatr Psychiatry 34: 692-699. Link: https://bit.ly/2WTeJ4w
6. Joana HC, Duarte-Silva ME, Ferreira AS (2018) Depressive vulnerability in women with Alzheimer's disease: relationship with personality traits and abnormal personality dimensions. Journal of Affective Disorders 24: 182-191. Link: https://bit.ly/2WRapmn

7. Johnson KG (2019) Women and risk for Alzheimer's disease. The Caregiver 37: $1-4$

8. Ladecola C (2015) Sugar and Alzheimer's disease: A bittersweet truth. Nat Neurosci 18: 477-478. Link: https://bit.ly/2Zq6X3F

9. Liu CC, Li CY, Hu SC (2019) Gender and age differences and the trend in the incidence and prevalence of dementia and Alzheimer disease in Taiwan: A 7-year national population -based study. BioMed Research International 1-12. Link: https://bit.ly/2WVy2ua

10. Michael K (2014) Cognitive and behavioral effects of sugar consumption in rodents: A review. Appetite 80: 1-5. Link: https://bit.ly/3edQMe9

11. Noble EE, Hsu TM, Liang J, Kanoski SE (2019) Early-life sugar consumption has long-term negative effects on memory function in male rats. Nutr Neurosci 22: 273-283. Link: https://bit.ly/3e8SDkb

12. Robinson R (2019) A rare variation of APOE delays Alzheimer's disease onset by decades: Now the field is focused on learning how. Neurology 19: 1-17.

13. Roksana K (2019) Apolipoprotein E4 genotype in combination with poor metabolic profile is associated with reduced cognitive performance in healthy postmenopausal women: implications for late onset Alzheimer's disease. Menopause 26: 7-15. Link: https://bit.ly/3bVxfNM

14. Shih EJ, Lee WJ, Hsu JL, Wang SJ, Fuh JL (2020) Effects of vitamin D on cognitive function and white matter hypersensitivity in patients with mild Alzheimer's disease. Geriatrics and Gerontology International 20: 52-58. Link: https://bit.ly/3gjrKw7

15. Sundermann EE, Biegon A, Rubin LH, Lipton RB, Landau S, et al. (2017) Does the female advantage in verbal memory contribute to understanding Alzheimer's disease pathology in women versus men? J Alzheimers Dis 56 947-957. Link: https://bit.ly/2TtiMlY

Discover a bigger Impact and Visibility of your article publication with

Peertechz Publications

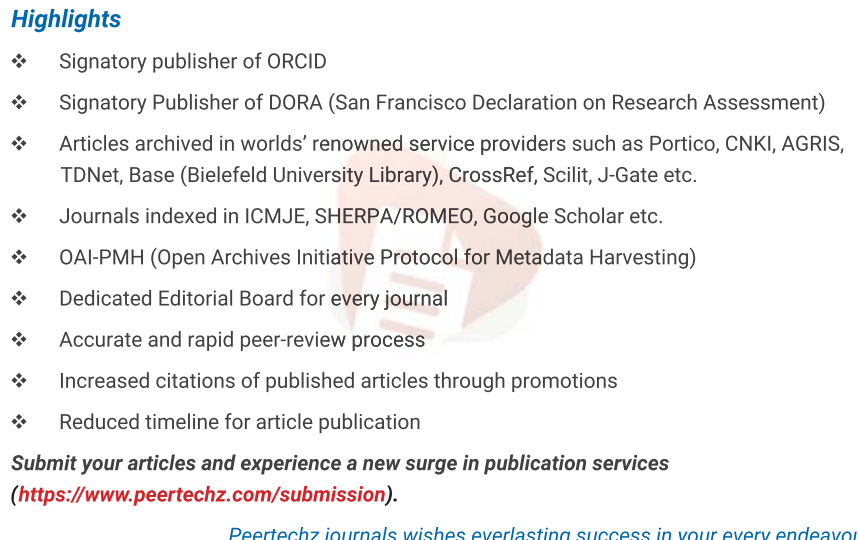

Peertechz journals wishes everlasting success in your every endeavours.

Copyright: @ 2020 Youngwanichsetha S. This is an open-access article distributed under the terms of the Creative Commons Attribution License, which permits unrestricted use, distribution, and reproduction in any medium, provided the original author and source are credited. 